\title{
EFFECT OF MOISTURE, TEMPERATURE, AND NITROGEN ON YIELD AND PROTEIN QUALITY OF THATCHER WHEAT
}

\author{
F. W. Sosulski, D. M. Lin, and E. A. Paul \\ University of Saskatchewan, Saskatoon, Saskatcbewan
}

Received April 28, 1966

\begin{abstract}
Soil moisture level was the most important factor controlling plant and grain yields while nitrogen fertilizer had the greatest influence on protein content and sedimentation value. Lower temperatures and nitrogen fertilization favored plant development at medium and high soil moisture levels but did not significantly alter the yield of plants subjected to periodic moisture stress. Temperature was the only treatment to have a consistent effect on kernel weight. However, seed yields were more closely associated with total plant weight and number of culms than kernel size.

The sedimentation values of the flour, which ranged from 33.8 to $70.7 \mathrm{ml}$, were highly correlated with protein content. The wide range of sedimentation values approached the maximum range reported for very weak and very strong wheats. Within treatments receiving the same nitrogen applications, the sedimentation values and protein content were inversely related to grain yield.

Variations in glutamic acid and proline content of the hydrolyzed flour proteins were positively associated with protein content and sedimentation value. Amino acids which were negatively correlated with protein content included alanine, arginine, aspartic acid, cystine, glycine, and lysine. Contrary to previous reports the lysine content varied over the complete range of protein content in the flours. The significance of these variations in amino acid composition are discussed in relation to recent studies on the fractionation of flour proteins.
\end{abstract}

\section{INTRODUCTION}

In previous experiments the protein content of Thatcher wheat was increased from 10.2 to $23.0 \%$ by controlling soil moisture and fertility levels (10). Changes in sedimentation values and mixing properties of the flours were positively associated with variations in protein content. Analyses of a limited number of samples indicated that the concentrations of nine amino acids in the grain and six amino acids in the flour were significantly correlated with total protein content. Hepburn and Bradley (3) have confirmed the reported trends in amino acid composition with changes in grain protein level.

The objectives of this study were to obtain further information on (1) the effects of moisture, temperature, and nitrogen treatments on the yield and protein content of Thatcher wheat and (2) the statistical relationships between amino acid composition and protein content of the flour. In addition to the 16 amino acids previously studied, cystine and tryptophan were also determined and a more accurate procedure was adopted for the estimation of methionine content.

\section{MATERIALS AND METHODS}

Plants of Thatcher wheat, sown at the rate of one plant per half-gallon pot, were grown under a constant daylength of 16 hours and light intensity of approximately $2500 \mathrm{ft}-\mathrm{c}$. Depending on the expected grain yields, between 12 and 28 plants per treatment were subjected to three soil moisture levels, two rates of nitrogen fertilization, and two temperature regimes. The design of the experiment was a randomized block with two replications.

The soil used was an Oxbow loam with a field capacity of $27 \%$ and permanent wilting percentage of $9 \%$. The soil moisture treatments were Can. J. Plant Sci. Vol. 46 (1966) 
regulated within the following three ranges: $27-18 \%, 27-14 \%$, and $27-10 \%$. The procedure for maintaining the moisture regimes has been previously described (10). Nitrogen in the form of ammonium nitrate was applied at the rates of 0 and $225 \mathrm{~kg} / \mathrm{ha}$. The $225-\mathrm{kg}$ rate was applied in four equal increments at 2 -week intervals beginning 14 days after planting. In addition, all pots were fertilized with phosphorus at the rate of $11 \mathrm{~kg} / \mathrm{ha}$. The experimental plants were grown at two constant levels: $18 \pm 1^{\circ} \mathrm{C}$ and $24 \pm 1^{\circ} \mathrm{C}$.

The harvested plants were air-dried before they were weighed. Plant and grain yields and kernel weights are reported on an as-is moisture basis. A portion of the threshed grain from each treatment was prepared for protein analysis by grinding in a Wiley mill. The remaining seed was milled to $65 \%$ extraction on a Geddes and Frisell experimental flour mill. Protein contents and sedimentation values were determined by standard procedures (1) and the values were corrected to a $14 \%$ moisture basis. Flour samples for amino acid analysis were hydrolyzed for 22 hours in $6 \mathrm{~N}$ hydrochloric acid at $120^{\circ} \mathrm{C}$ in an atmosphere of nitrogen. The distribution of 15 amino acids and ammonia in the hydrolyzed proteins was determined by ion exchange chromatography (7). Cystine and methionine were assayed as cysteic acid and methionine sulfone following preoxidation of the flour samples with performic acid (6). Tryptophan was chromatographed on a potato starch column after hydrolysis of the flour with barium hydroxide (11).

Except for cystine and methionine values, all data presented in this paper are the means of two replications. Plant and grain vields are reported on a per-plant basis.

\section{RESULTS}

Plant and grain yields were increased by conditions of lower temperature, higher moisture level, and nitrogen fertilization (Table 1). The effects of temperature and fertilizer were significant only at medium and high moisture

Table 1. Influence of temperature, moisture, and nitrogen on the agronomic and quality characteristics of Thatcher wheat

(Sed. = sedimentation)

\begin{tabular}{|c|c|c|c|c|c|c|c|}
\hline Temp. $\left({ }^{\circ} \mathrm{C}\right)$ & $\begin{array}{c}\text { Moisture } \\
\text { regime } \\
(\%)\end{array}$ & $\begin{array}{l}\text { Plant } \\
\text { weight } \\
\quad(g)\end{array}$ & $\begin{array}{l}\text { Grain } \\
\text { yield } \\
(\mathrm{g})\end{array}$ & $\begin{array}{c}\text { Kernel } \\
\text { weight } \\
\text { (mg) }\end{array}$ & $\begin{array}{c}\text { Grain } \\
\text { protein } \\
(\%)\end{array}$ & $\begin{array}{c}\text { Flour } \\
\text { protein } \\
(\%)\end{array}$ & $\begin{array}{l}\text { Sed. } \\
\text { value } \\
(\mathrm{ml})\end{array}$ \\
\hline \multicolumn{8}{|c|}{ No nitrogen added } \\
\hline \multirow[t]{3}{*}{18} & $27-18$ & $21.7 c^{*}$ & $4.0 b c$ & $27.5 a b c$ & $10.9 a$ & $10.2 a$ & $33.8 a$ \\
\hline & $27-14$ & $19.1 b c$ & $3.7 b$ & $27.5 a b c$ & $11.6 a b$ & $10.6 a$ & $42.5 b$ \\
\hline & $27-10$ & $10.8 a$ & $2.7 a b$ & $29.3 b c$ & $12.3 b$ & $11.5 a$ & $57.0 c$ \\
\hline \multirow[t]{3}{*}{24} & $27-18$ & 15. $1 a b c$ & $2.2 a$ & $25.6 a b$ & $12.7 b$ & $10.8 a$ & $39.9 a b$ \\
\hline & $27-14$ & $15.0 a b c$ & $2.4 a$ & $25.9 a b$ & $12.5 b$ & $11.0 a$ & 45.96 \\
\hline & $27-10$ & $10.0 a$ & $1.7 a$ & $27.9 a b c$ & $15.6 c d$ & $13.7 b c$ & $61.5 c d$ \\
\hline \multicolumn{8}{|c|}{ Nitrogen added at $225 \mathrm{~kg} / \mathrm{ha}$} \\
\hline \multirow[t]{3}{*}{18} & $27-18$ & $33.5 d$ & 7.5 & $31.1 c$ & $13.0 b$ & $12.9 b$ & $58.5 c$ \\
\hline & $27-14$ & $29.1 d$ & $6.0 d$ & $29.8 b c$ & $15.0 c$ & $14.2 b c$ & $68.3 d$ \\
\hline & $27-10$ & $14.0 a b c$ & $2.3 a$ & $27.5 a b c$ & $16.3 c d$ & $15.7 d e$ & $70.7 d$ \\
\hline \multirow[t]{3}{*}{24} & $27-18$ & $21.9 c$ & $5.2 c d$ & $27.0 a b c$ & $16.1 \mathrm{~cd}$ & $14.7 c d$ & $65.1 \mathrm{~cd}$ \\
\hline & $27-14$ & $18.7 b c$ & $3.8 b$ & $26.2 a b$ & $16.9 \mathrm{de}$ & $16.2 e$ & $68.9 d$ \\
\hline & $27-10$ & $12.3 a b$ & $2.2 a$ & $23.9 a$ & $17.9 e$ & $17.0 e$ & $70.0 d$ \\
\hline
\end{tabular}

* Means with like letters do not differ significantly $(P<0.05)$ by the Duncan multiple range test. 
Table 2. Variance ratios $(F)$ of the main effects and interactions of temperature, moisture, and nitrogen on the plant characteristics and quality of Thatcher wheat

(Sed. = sedimentation)

\begin{tabular}{lccccccc}
\hline \multicolumn{1}{c}{ Source } & D.F. & $\begin{array}{c}\text { Plant } \\
\text { weight }\end{array}$ & $\begin{array}{c}\text { Grain } \\
\text { yield }\end{array}$ & $\begin{array}{c}\text { Kernel } \\
\text { weight }\end{array}$ & $\begin{array}{c}\text { Grain } \\
\text { protin }\end{array}$ & $\begin{array}{c}\text { Flour } \\
\text { prot }-i n\end{array}$ & $\begin{array}{c}\text { Sed. } \\
\text { valu? }\end{array}$ \\
\hline Temperature & 1 & $19.0^{* *}$ & $41.9^{* *}$ & $14.0^{* *}$ & $78.1^{* *}$ & $34.8^{* *}$ & 4.2 \\
Moisture & 2 & $25.9^{* *}$ & $43.0^{* *}$ & 0.1 & $34.2^{* *}$ & $33.5^{* *}$ & $29.3^{* *}$ \\
Nitrogen & 1 & $21.8^{* *}$ & $57.3^{* *}$ & 0.3 & $197.0^{* *}$ & $262.6^{* *}$ & $184.0^{* *}$ \\
T $\times \mathrm{M}$ & 2 & 3.1 & $4.4^{*}$ & 0.0 & 0.2 & 0.1 & 0.8 \\
$\mathrm{~T} \times \mathrm{N}$ & 1 & 2.3 & 0.0 & 2.3 & 0.0 & 1.6 & 0.6 \\
$\mathrm{M} \times \mathrm{N}$ & 2 & 2.0 & $16.6^{* *}$ & $5.1^{*}$ & 0.2 & 1.7 & $7.4^{* *}$ \\
$\mathrm{~T} \times \mathrm{M} \times \mathrm{N}$ & 2 & 0.4 & 1.4 & 0.0 & 4.2 & 2.3 & 0.3 \\
\hline
\end{tabular}

*Significant at $P=0.05$. * Significant at. $P=0.01$

levels. Plant and grain weights were markedly depressed when the soil moisture level in the pots was periodically reduced to near the wilting point. However, the differences in grain yield between the $27-10 \%$ and higher soil moisture levels were significant only in the fertilized pots. This interaction of moisture with nitrogen on grain yield was highly significant (Table 2).

In general the kernel weight decreased with increasing levels of available moisture in the non-fertilized treatments but showed a reverse trend when nitrogen was applied. Temperature was the only environmental factor to have a consistent influence on kernel weight with lower temperatures favoring larger kernel size. The greater yields obtained at the lower temperature were partially due to increased kernel weight. Since temperature was controlled independently of moisture level, this study provides evidence that temperature has a direct effect on one of the components of yield.

The protein content of the grain varied from 10.9 to $17.9 \%$. Although significant changes in protein content were associated with variations in level of each factor, nitrogen fertilization was the principal factor controlling the protein content of the grain. This result was not unexpected in view of the high rate of nitrogen used and its application in increments up to the time of heading. The flours were approximately $1 \%$ lower in protein content than the grain.

Sedimentation values were increased by lower soil moisture and nitrogen application but were not affected by temperature. The high moisture $\times$ nitrogen interaction was due to the greater response of sedimentation value to moisture level in the non-fertilized pots than in those receiving supplementary nitrogen. A highly significant correlation coefficient, $+0.93^{* *}$, was obtained between sedimentation value and flour protein content. The principal difference between the two quality tests was the greater range in sedimentation value under the low nitrogen treatments whereas protein content was more variable in the nitrogen-fertilized treatments. The wide range in sedimentation values obtained in this study approaches the maximum range reported for very weak and very strong wheats $(9)$.

The results of the amino acid analyses are presented in order of increasing flour protein content (Table 3). The amino acids and ammonia accounted for over $95 \%$ of the total Kjeldahl nitrogen in the flour. This level of recovery exceeds the total values obtained in the previous study (10) where 


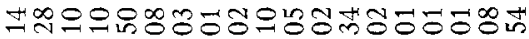

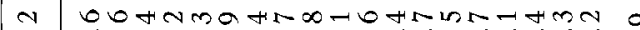

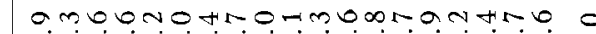

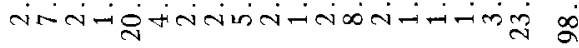

matam-tua onogonemmt H

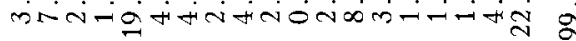

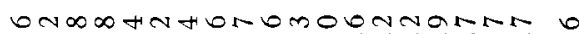

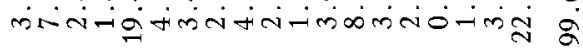

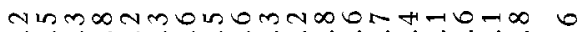

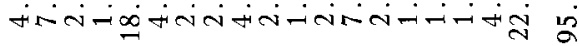

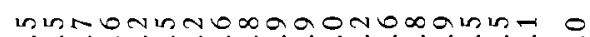

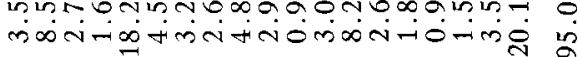
anmo-isanumoganoofth

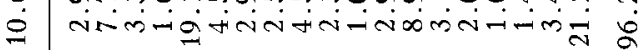

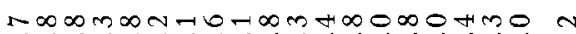

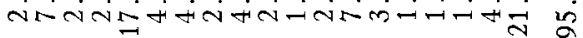

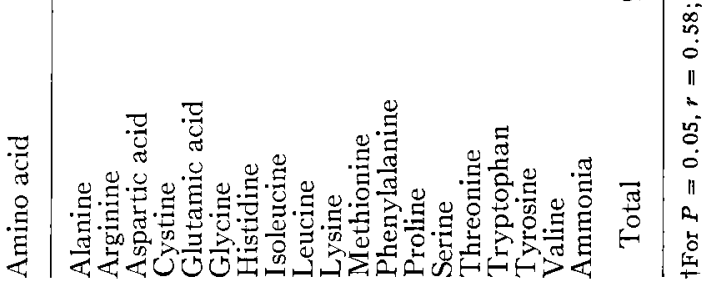


cystine and tryptophan were not determined. The standard deviations per determination of each amino acid, which were calculated on the basis of two replications, were higher than those reported by Sosulski et al. (10) for duplicate determinations on the same sample.

As previously demonstrated (10), glutamic acid, proline, and arginine were the principal amino acids found in the flour proteins. The regression coefficients indicate that the above-noted amino acids also show the greatest quantitative change per unit increase in protein content. Glutamic acid and proline were positively correlated with protein content while alanine, arginine, aspartic acid, cystine, glycine, and lysine gave significant negative correlations. The yields of ammonia were closely associated with the concentrations of glutamic acid.

Correlations of amino acids with sedimentation value were also calculated. The coefficients were nearly identical with those obtained with protein content and so the values are not reported. However, the relationship between alanine and sedimentation value $(r=-0.44)$ was not significant.

\section{DISCUSSION AND CONCLUSIONS}

Grain yield per plant is a function of the number of heads, the number of kernels per head, and the kernel weight. In the present study, the total plant weight gave a very high correlation, $+0.97^{* *}$, with grain yield. Since the plants were sown at the rate of one plant per pot there were no physical restrictions to culm development and their number varied markedly with treatment. A highly significant correlation $(r=+0.92)$ between number of culms and grain yield was obtained. The relationship of number of kernels per head $\left(r=+0.74^{* *}\right)$ and kernel weight $\left(r=+0.67^{*}\right)$ to yield was also calculated. The relative order of these coefficients is in agreement with components of yield experiments conducted in the field (5).

When grown in medium-textured soils, the plant development of Thatcher wheat was markedly influenced by moisture level $(2,4)$. Plants subjected to periodic wilting produced less than one-fourth of the plant and seed yields obtained when soil moisture was maintained continuously above $50 \%$ of field capacity (4). Although wilting was not induced in the present experiment, plant and seed yields were more than doubled by increasing the minimum soil moisture level from 10 to $18 \%$ in the fertilized treatments. Surprisingly, the yields of plants subjected to frequent soil moisture stress were similar under both temperature regimes. However, the expected greater yields due to lower temperatures were obtained at the medium and high moisture levels.

When calculated on the basis of all treatments, the correlation coefficient between grain yield and protein content $(r=-0.11)$ was very low and nonsignificant. The poor correlation was due to the more marked influence of nitrogen application on protein content than on grain yield (Table 1). Within treatments receiving the same nitrogen applications, the protein content and sedimentation values were inversely related to grain yield. The correlation coefficient between yield and protein content was $-0.86^{*}$ for the non-fertilized treatments and $-0.90^{*}$ for those receiving $225 \mathrm{~kg}$ of nitrogen per hectare.

Certain amino acids have been shown to vary with protein content. In particular, arginine and lysine tend to vary in inverse proportion to glutamic 
acid (8). In a preliminary study, glutamic acid, isoleucine, and proline were positively associated with protein content, sedimentation value, and mixogram data (10). Arginine, aspartic acid, and lysine were negatively correlated with these flour quality tests. Analysis of a much larger number of samples in the present study confirms the positive correlation of glutamic acid and proline with protein content and sedimentation value. Isoleucine failed to show any relationship with flour quality but alanine, cystine, and glycine were additional amino acids which gave significant negative correlations. It is generally accepted that the lysine content of whole wheat does not vary significantly in samples containing more than $13.5 \%$ protein (8). The data for flours (Table 3 ) show the inverse relationship of lysine with protein content to occur over the full range of protein values studied.

The gluten-forming proteins in wheat flour govern to a large extent the plastic and elastic properties of bread doughs. Glutamic acid and proline constitute over one-half of the total amino acids in gluten (12). Soluble proteins, which do not form a part of the gluten complex, are relatively high in alanine, arginine, aspartic acid, cystine, and lysine $(8)$. The trends in amino acid composition reported in the present paper support the conclusion of Pence et al. (8) that gluten-forming proteins not only increase in absolute amounts in flours with higher protein, but also constitute a greater percentage of the total flour proteins.

\section{ACKNOWLEDGMENT}

The financial assistance provided by the National Research Council of Canada is gratefully acknowledged.

\section{REFERENCES}

1. American Association of Cereal Chemists. 1962. Cereal laboratory methods. St. Paul, Minn.

2. Dubetz, S. 1961. Effect of soil type, soil moisture and nitrogen fertilizer on the growth of spring wheat. Can. J. Soil Sci. 41, 44-51.

3. Hepblrs, F. N. and Bradley, W. B. 1965. The amino acid composition of hard wheat varieties as a function of nitrogen content. Cereal Chem. 42, 140-1.49.

4. Hutcheon, W. L. and Rennie, D. A. 1960. The relationship of soil moisture stress and nutricnt availability to the growth characteristics and quality of wheat. Trans. 7th Intern. Congr. Soil Sci. Vol. 3. pp. 488-495.

5. Locke, L. F., Rauchschwalbe, O. E., and Mathews, O. R. 1942. The relations to yield of certain plant characters of winter wheat as influenced by different tillage and sequence treatments. J. Am. Soc. Agron. 34, 628-645.

6. Moore, S. 1963. On the detcrmination of cystine as cysteic acid. J. Biol, Chem. 238, 235-237.

7. Moore, S., Spackman, D. H., and Stern, W. H. 1958. Chromatography of amino acids on sulfonated polystyrene resins. Anal. Chem. 30, 1185-1190.

8. Pence, J. W. Nimmo, C. C., and Hepbern, F. N. 1964. Proteins. In Wheat chemistry and technology. Edited by I. Hlynka. pp. 227-276. Am. Assoc. Cereal Chemists, St. Paul, Minn.

9. Pinckney, A. J., Greenaway, W. T., and Zeleny, L. 1957. Further development in the sedimentation test for wheat quality. Cercal Chem. 34, 16-25.

10. Sosulski, F. W., Paul, E. A., and Hutcheon, W. L. 1963. The influence of soil moisture, nitrogen fertilization, and temperature on quality and amino acid composition of Thatcher wheat. Can. J. Soil Sci. 43, 219-228.

11. Stein, W. H. and Moore, S. 1948. Chromatography of amino acids on starch columns. J. Biol. Chem. 176, 337-365.

12. Woychik, J. H., Boundy, J. A., and Dimler, R. J. 1961. Amino acid composition of proteins in wheat gluten. J. Agr. Food Chem. 9, 307-310. 